\title{
Mamang Dai's poetry: challenges in translating ecofeminism
}

\author{
Antonia Navarro Tejero*
}

\begin{abstract}
Mamang Dai, an Adi poet from the Northeastern part of India, celebrates the ecological glory of her region Arunachal Pradesh in her collections of poetry written in English. In this paper, I propose to make a textual analysis of "Tapu" and "An Obscure Place," two of the poems included in the bilingual edition entitled The Balm of Time (2008), where I contributed as a translator, paying special attention to the ecofeminist awareness, inspiration from folktales, and nature im-ageries that are related to the issue of identity.
\end{abstract}

Key words: ecofeminism, Mamang Dai, North-East India

\section{Introduction}

Ecological criticism is methodologically similar to other forms of cultural criticism such as Post Colonialism and feminist criticism. It is interesting to notice that Postcolonial Studies and Ecocriticism have many elements in common when dealing with the subaltern position. Graham Huggan and Helen Tiffin, two of the founders of Postcolonial Theory, published in 2010 their Postcolonial Ecocriticism: Literature, Animals, Environment. On the other hand, ecofeminism emerged as a product of the peace, feminist and ecology movements of the late 1970s and the early 1980s. The term was coined by the French writer Francoise d'Eaubonne in her Le Féminisme ou la Mort (1974), and was further developed by Ynestra King in 1976. The first ecofeminist conference "Women and Life on Earth: Ecofeminism in the 80s" was held at Amherst, Massachusetts, US (Spretnak 1990). However, in the case of India, ecofeminist postcolonialism has emerged as a theoretical framework that involves the three trends. As Vandana Shiva puts it: "Indian women have been at the forefront of ecological struggles to conserve forests, land and water. They have challenged the western concept of nature as an object of exploitation and have protected her as Prakriti, the living force that supports life" (xvii).

Many Indian poems in English have portrayed the gradual deterioration of the earth's environment and ecology. In order to unveil how these concepts are interrelated, we have chosen to focus on Mamang Dai, an Adi poet from North

\footnotetext{
* University of Cordoba, Cordoba, Spain; The author wishes to acknowledge the funding provided by the Spanish Ministry of Economy and Competitiveness (Research Project "Bodies in Transit", ref. FFI2013-47789-C2-1-P) and the European Regional Development Fund for the writing of this essay.
} 
of the Brahmaputra River in Arunachal Pradesh, the Northeastern part of India, who celebrates the ecological glory of her region in her collections of poetry written in English. In order to contextualise her writing, we need to know that there are many components of the complex mix of forces that have impacted local cultural practices of the ethnic groups in North East India: dozens of officially recognised ethnic groups reside in these multi-ethnic areas, many of them speak Tibeto-Burman, Mon-Khmer, or Tai languages; a large percentage of the native population has been classified as Mongoloid by Indian anthropologists; effects of historic and prehistoric interactions between lowland and upland ethnic groups; effects of a-historic and historic migrations from China and South East Asia; the British colonial tradition dating from 1826, whose Catholic and Protestant missionaries brought sects of christianity; incorporation of the area into India beginning 1947; isolation from neighbouring countries and other parts of India; a vast array of independence and separatist movements, some of which transcend national boundaries into Myanmar and other states; growing immigrant communities from Bangladesh and other areas; Hinduization, modernization, environmental transition, and globalization. As a consequence, among North East Indian poets, there are dominant themes in their writings such as nationhood, identity, insurgency, ethnic violence, corruption in the bureaucracy, home, migration, exile, memory, or regional ecological concern. Eco-consciousness is a significant feature in the writings of these authors, and particularly Mamang Dai exposes the ethos of nature and communities in her poetry.

\section{Background}

Mamang Dai was born in Pasighat, East Siang District, in 1957. She is an accredited journalist, and was a programme officer with World Wide Fund for Nature during the first years of its establishment in the state, and worked with the bio-diversity Hotspots Conservation programme in the field of research, survey and protection of the flora and fauna of the eastern Himalayas. She is the first woman from her state to be selected to the Indian Administrative service which she left to pursue a career in journalism. Dai was a correspondent of the Hindustan Times, the Telegraph and The Sentinel newspapers and President of the Arunachal Pradesh Union of Working journalists. A former member of the Indian Administrative Service, she left the service to pursue a career in writing. She is now a member of both the North East Writers' Forum, and the Arunachal Pradesh Public Service Commission. She has published poems and short stories in journals and magazines, and has received the Verrier Elwin Award from the State government of Arunachal Pradesh in 2003, and the Padma Shri from the Government of India in 2011. Her popular works include Arunachal Pradesh: The Hidden Land (2009), Once upon a Moontime: From the Magical Story World of Arunachal Pradesh (2005), The Sky Queen (2005), 
River Poems (2004), and two novels, Stupid Cupid (2009) and The Legends of Pensam (2006), which deals with the ecology of Arunachal Pradesh by merging history, myth, tradition, memory and fiction together. The story revolves around the myths, legends, tradition and culture of the 'Adis', and re-invents that part of history which is yet unexposed. A world with ecofeministic ideals is vividly seen through the clash between tradition and modernity. She touches upon same topics and sensibilities in her poetry, where she reveals the myriad world of Arunachal's ecology, and its mysterious and glorious heritage.

Dai lives in Itanagar, but has travelled extensively in India and abroad. We invited her to Córdoba, Spain, in 2008 to participate in a Workshop on Poetry translation along with Indian poet Keki Daruwalla. This is a Seminar that is celebrated on a yearly basis by the organisers poets Bernd Dietz and Francisco Gálvez, who decided to focus on Indian poets due to the existence of our Permanent Seminar on India Studies at the University of Córdoba. I was requested to propose two names and participate as a language translator and culture interpreter. I chose Mamang Dai because I considered she does not receive appropriate attention on the global stage in spite of writing in English and of the global phenomena of local poetic traditions among ethnic and native populations. Furthermore, there were no Spanish editions of her writing for which we ended up publishing two pieces: a bilingual anthology entitled The Balm of Time, and a selection of the bilingual poems in the literary journal La Manzana Poética. In the Balm of Time, we translated twenty-three poems, selected by Mamang Dai and with the joint work of two renewed Spanish poets (José Luis Rey and Francisco Gálvez) who cannot speak English, and myself, who worked as a bridge between the poet (who was present during the whole process) in language and in culture. We paid special attention to the ecological awareness, inspiration from folktales, and nature imageries that are related to the issue of identity, mountains, streams, rivers and stones, myths and nature's magic, native people's faiths, and her own. In this paper, I will discuss two of the poems: "Tapu" and "An Obscure Place."

\section{Analysis}

Dai's poems are an expression of an individual poetic self as well as the saga of the people of the region in general. One of the strategies that Dai explores, as many other ethnic minority poets, is the use of traditional local knowledge or folklore. There are numerous images of intangible culture such as songs, rituals, myths, native language, and local landscape in this selection. The spectral world of spirits, gods and goddesses is also incorporated in her poetry. There are also allusions to exemplary males, highlighting the importance of women and children. We are told local practices such as dancing and hunting. In each one of the twenty-three poems, the use of folklore is the ancestral cord towards the roots of her regional landscape. She recovers the traditional tribal values 
as an act of collective identity and healing a wonder region by overcoming the violence it has been subjected to. "Tapu" is divided into two parts. An initial one where the poetic I highlights the heroic nature of the warriors having completed their duties:

Here we have marked the land

with upright branches and stones

and consecrated territory

with song, and the leap of the warrior

returning triumphant.

In this diagram

looking through the sun's face,

peeping through the moon,

the meaning of life is contained

in fulfilling obligation.

Mark the sword.

Mark the sound.

This makes allusion to the dance ritual that the poet felt she had to explain in a footnote that reads "Tapu is a dance performed by men during the time of community fencing. Today it is viewed as a war dance performed to exorcise malevolent sports" (27). Such traditional events in North-East India have become important contexts for constructing, negotiating, and displaying ethnic identity (song, dance, and costume).

However, the poem continues focusing on the simile of conception. The footnote keeps reading "but once there was a belief that women who had borne no sons could put on male attire and join the dancers in the hope of conceiving a son" (27). This belief has remained in the periphery of knowledge, as in any representation of Tapu ritual, there are no women involved, and the visual "sword" and acoustical "sound" signs are only related to war. In the next stanza of the poem, the poetic I wonders:

What are the words

we will tell our sons and daughters?

That dying is not so hard

if the image survives.

With this, the poet calls on her people to attend to the neglected side of this tradition, which has become a tourist ethnic attraction nowadays, as we can check in the many festival grounds sponsored by local governments. 
The poem here swifts to the idea of conception as a simile to the fencing ritual:

When the wind is young

sow celebration,

seize the branch of lighting,

dress the thorn wood stem

for conception.

Across the barren earth

the fence stretches the boundaries

of the natural world.

In the last part of the poem, the poet represents a scenario where women perform the dance ritual, ending up with the same image of the cyclical nature of the sun as for the one performed by warriors:

children are for the blessed.

only in dreams we hear

the sighs of the unborn.

In the eternal landscape

of hope and longing

alchemy happens with faith.

Driving the spirit of fear into the dust

like a mirage

the mountains range themselves

blue flashing, in the circle of the sun.

Many of the poems in this selection speak on the subject invoking the dynamic of change and continuity in tradition. For example, "An Obscure Place" deals with the opposition between official History and traditional stories, with a sense of alienation and displacement:

The History of our race begins with the place of stories.

We do not know if the language we speak

belongs to a written past.

Nothing is certain.

In the next few lines, the poetic I speaks of the consequences of the masculine 
battles for homeland, as there is no compensation for death:

There are mountains. Oh! There are mountains.

We climbed every slope. We slept by the river.

But do not speak of victory yet!

An obscure place haunts the hunter.

The prize slips away.

Yesterday the women hid their faces.

They forbade their children to speak.

yesterday we gave shelter to men

who climbed over our hills

for glory of a homeland, they said -

those who know what knowing is,

And now the sleeping houses, the men and the villages

have turned to stone.

The poetic I focuses in the next few lines on how media covers the news and the fear of those who come to conquer and destroy their natural land. The close relationship that the native people had with the wilderness is falling apart. The destruction of flora and fauna is a concern in the poem, connected to the maternal. It also serves as a metaphor of lost identity as nature in a holistic way represents the collective identity of the people. This can be interpreted as a powerful way of asserting her people's own identity amidst cultural and political hegemony:

If there is no death the news is silent.

If there is only silence, we should be disturbed

Listen, the tone of a prayer is hushed:

If a stranger passes this way let him look up to the sky.

A smoke cloud chases the ants.

See! They have slain the wild cat

and buried the hornbill in her maternal sleep.

The words of strangers have led us into a mist

deeper than the one we left behind 
weeping, like a waving grassland

where the bones of our fathers are buried

surrounded by thoughts of beauty.

The poem ends with a repetition of images of the mountains, rivers. Here, the mountains cease to be just another landscape and instead is treated as a subject in the conglomeration of nature and history. Through the mountains, she seeks the ancestral cord to lead her back to the lost roots:

There are mountains. Oh! There are mountains.

We climbed every slope. We slept by the river.

But do not speak of victory yet! (13-14)

The very name Arunachal Pradesh means The Land of the Dawn Lit Mountains from Sanskrit, as this state receives the first rays of the sun in the country, and is moreover one of the greenest parts of India. The mountains, in Dai's poems, are omniscient, and as Vohra states, they embody not only "the collective consciousness of hope of a people but also .... the fears and lost expectations in an increasingly complicated and changing society" (47). Mamang Dai in the article "The Nature of Faith and Worship among the Adis" remarks that the great forest, the mountains and the environment shaped the consciousness of the Adi people and made them decorate the Pator Gate (a gate made of leaves and branches and considered holy) with arrows tipped with ginger and the sacred branches of the 'Taan' tree to consecrate it against evil forces.

Many of her poems seem to advocate preservation of culture and tradition. The nature imaginary is related to identity and fluidity, tradition and culture, in contrast to modernisation. Nature is portrayed as an extension of the ancestral roots. She is the speaking voice of tradition-bearers located at the nexus between the fading past and the emergent new, as there are many allusions to cultural change, and minority status by a nostalgic poetic I. The word "revival" appears in almost every poem, so we can argue that her poetry is a vehicle for cultural transmission. A cry for a mother-tongue language lost. All these features will lead us to classify Mamang Dai as a folklore writer (Greet, 4). The poet, as a modern journalist woman, assumes a dual role as tradition-bearer and innovator, in the dynamics of social and ecological change for cultural sustainability, in the creation of ethnic images and identity for multiple audiences.

\section{Conclusion}

Vandana Shiva has recently stated in an interview with Spanish newspaper La Vanguardia that ecofeminism is the way towards the world biocivilization, which she claims make us conscious that humans are part of the Earth, not a 
separate being. Only when we change our economic model, we will put an end to patriarchy: climate change, inequality, lack of solidarity, war... Ecofeminism would end up with this unhealthy and irresponsible toxic project of domination over nature and women. Nature would live, it would be sustainable.

\section{References:}

Dai 2008. Dai M. Selected Translated Poems. Trans. Rey J. L., Tejero A. N., F. Gálvez. Revista de Literatura 24 (diciembre 2008): 41-50. ISSN 1887-7184.

--. El Bálsamo del tiempo (The Balm of Time). Trans. Rey J. L., Tejero A. N., F. Gálvez. Córdoba: La manzana poética. 2008. ISBN 978-84-93599-74-4.

--. "The Nature of Faith among the Adis" Understanding Tribal Religion. Ed Mibang. Mibang,

Chaudhuri, Chaudhuri 2004. Chaudhuri T., S. K. Chaudhuri. Understanding Tribal Religion. Mittal Pulishers, 2004.

--. Arunachal Pradesh: The Hidden Land. 2009.

--. Once upon a Moontime: From the Magical Story World of Arunachal Pradesh. 2005.

--. The Sky Queen. 2005.

--. River Poems. 2004.

--. Stupid Cupid. 2009.

--. The Legends of Pensam. 2006.

D’Eaubonne 1974. D’Eaubonne F. Le Féminisme ou la Mort. 1974.

Gokak 2011. Gokak V. K. "Introduction.” In Gokak V. K. (ed.). The Golden Treasury of Indo-Anglian Poetry. New Delhi: Sahitya Academy, 2011. (in print).

Huggan, Tiffin 2010. Huggan G., H. Tiffin. Postcolonial Ecocriticism: Literature, Animals, Environment. London: Routledge, 2010.

Shiva 2016. Shiva V. "El patriarcado destruirá el planeta si no lo frenamos" Interview with Víctor Amela, Ima Sanchís and Lluís Amiguet. La Vanguardia 09/05/2016 VÍCTOR AMELA http://www.lavanguardia.com/television/20160608/402368678750/asi-ven-losninos-a-rajoy-aseado-y-que-habla-raro.html

--. Staying Alive: Women, Ecology and Development. London: Zed Book, 1989.

Vohra 2013. Vohra H. "Symbolism of the Mountains: A Study of Selected Poems of Mamang Dai” NEHU Journal, Vol XI, No. 1, January 2013, 45-54. 